\title{
AUSTRALIAN BLACK BEETLE EXPANSION THROUGH CHRISTCHURCH CITY HIGHLIGHTS A RISK TO PASTORAL AGRICULTURE ON THE CANTERBURY PLAINS
}

\author{
R.J. TOWNSEND, M.R. MCNEILL and T.A. JACKSON \\ AgResearch, Lincoln, Private Bag 4749, Christchurch 8140, New Zealand \\ Corresponding author: richard.townsend@agresearch.co.nz
}

The Australian black beetle, Adoryphorus couloni (also known as the red-headed cockchafer), was found in large numbers in Barrington Park in Christchurch in May 2008. Severely damaged areas comprised $10-20 \%$ of the park, with populations reaching over 300 larvae $/ \mathrm{m}^{2}$. The thatch layer produced on sports fields appears ideal for this insect, which favours grasslands with high organic matter levels, and could explain the very high grub numbers. To reach a population of this size, A. couloni had probably colonised and remained undetected in the park for several years. In Australia the insect is a serious pest of pastures. Severe damage occurred in Tasmania in the 1980s and 1990s when the insect spread through the central Midlands, stripping bare thousands of hectares of pasture. The beetle was accidentally introduced to Canterbury through Lyttelton harbour in the 1960s and has slowly spread around the Port Hills in low-quality hill pastures. The outbreak in Christchurch marks the first move of this pest into habitat favourable for development of populations large enough to pose a serious risk of further westward expansion onto the Canterbury plains. AgResearch is assisting the Christchurch City Council with identification and control recommendations for the pest and is evaluating potential biocontrol measures.

\section{BIOCONTROL - A POSSIBILE OPTION TO CONTROL MANUKA BEETLE (PYRONOTA SPP.) CAUSING PASTURE DAMAGE ON DAIRY FARMS ON THE WEST COAST}

\author{
R.J. TOWNSEND and T.A. JACKSON \\ AgResearch, Lincoln, Private Bag 4749, Christchurch 8140, New Zealand \\ Corresponding author: richard.townsend@agresearch.co.nz
}

Manuka beetle (Pyronota spp. Bois., Coleoptera: Scarabaeidae) has often been reported causing pasture damage, frequently in areas close to bush margins. Larvae feed on the roots of pasture species, producing damage that is often attributed to grass grub (Costelytra zealandica). During 2006-07 significant pasture damage was observed in dairy pastures established on 'flipped' developments on sandy soils near Cape Foulwind and on 'hump and hollow' developments near Bell Hill, north of Lake Brunner. Sampling revealed damage was caused by high populations of manuka beetle larvae; no grass grubs were found in either region. The common manuka beetle, Pyronota festiva, was identified from both areas and a second Pyronota species (P. edwardsi or P. setosa) was found only on the sandy soils at Cape Foulwind. A pathogen survey of Pyronota larvae from both regions showed very low levels of infection by bacterial and protozoan pathogens but did reveal moderate infection by the fungi Metarhizium and Beauveria in $3^{\text {rd }}$ instar larvae. A laboratory bioassay at $15^{\circ} \mathrm{C}$ showed late third instar Pyronota spp. larvae were susceptible to infection by Metarhizium anisopliae and Beauveria bassiana spores mixed into soil. Further work will evaluate a promising local Beauveria brongniartii isolate as a biocontrol option against this emerging pest. 